may apply for Osteopathic Recognition. Osteopathic Recognition signifies that the program is committed to teach and assess Osteopathic Principles and Practice at the GME level. Osteopathic Principles and Practice recognize that the patient is a unit of mind, body, and spirit; that the body has the intrinsic ability to heal itself when provided with the right environmental conditions; and that structure and function are interrelated. Both students who have graduated from osteopathic- and LCME-accredited schools may enter into a program's designated osteopathic-focused track.

Osteopathic Recognition is designed to provide an organized approach to perpetuate osteopathy's contributions to patient care and to create opportunities for all physicians to learn Osteopathic Principles and Practices while creating program distinctiveness. (http:// www.acgme.org/Portals/0/PDFs/FAQ/Osteopathic\%20 Recognition\%20FAQs.pdf h $_{i}$ ttp://www.acgme.org/Portals/0/PFAssets/ProgramResources/Elements_of_an_ Osteopathic_Learning_Environment.pdf)

4. The 4 th dimension of the agreement is the incorporation of the $\mathrm{AOA}$ and $\mathrm{AACOM}$ into the governance structure of ACGME. This will include board of director seats and playing a role in nominating representatives to various residency committees.

In February 2014, after more than a decade of discussions and 2 years of in-depth planning, the AOA and ACGME announced their intent to create a single GME accreditation system. This historic change has profound implications for both AOA- and ACGME-accredited programs. As of June 2016, 21 family medicine programs have applied for and 5 family medicine programs have received initial accreditation status under the single accreditation system. It is anticipated that more family medicine programs will begin the process when their institution receives preaccreditation status.

The AFMRD, in collaboration with the ACOFP, has developed the Accreditation Navigation program to assist AOA program directors in the transition to ACGME Family Medicine accreditation. The Accreditation Navigation program is based on the popular and very successful National Institute for Program Director Development (NIPDD) program. The AFMRD and the family of family medicine organizations are poised to assist and welcome our osteopathic colleagues. A single accreditation system will provide excellent benefits for osteopathic and allopathic students who are dedicated and interested in providing patient-centered and focused health care.

Thomas Miller, $M D_{i}$ James Jarvis, $M D_{i}$ Karen Mitchell, $M D, W$. Fred Miser, $M D$
From the North PRIMARY CARE American Primary Care
RESEARCH GROUP Research Group

Ann Fam Med 2016;14:384-386. doi: 10.1370/afm.1959.

\section{A GRATEFUL TRIBUTE TO MAURICE WOOD: FOUNDING PRESIDENT OF THE NORTH AMERICAN PRIMARY CARE RESEARCH GROUP}

For more than 60 years Maurice Wood was a passionate advocate for primary care, best evidence, academic research, and the generalist physician's role, in the United Kingdom, United States, and around the world. ${ }^{1}$ He died at home on March 11, 2016 at 93 years of age, leaving a stunning legacy of friendship, doctoring, leadership, investigation, mentoring, and inspiration for generations of health professionals. ${ }^{2-4}$ To add to the outpouring of gratitude and respect that burst forth for Maurice when news of his passing spread around the world, past presidents of NAPCRG and Wood Award winners voiced personal recollections about this amazing man, the person beloved by so many.

Kurt Stange: "Maurice taught me, (taught all of us), by deed more than by dialogue, that it is possible, actually that it is imperative, to marry intellectual rigor and perseverance with interpersonal kindness, when one is doing something as important as striving to discover how illness happens and how health can be strengthened. His approach lives on in our best individual and collective selves."

Bill Phillips: "Maurice Wood was a man of short stature who cast a shadow long enough to cross the Atlantic and wrap the world around. His heart was big enough to embrace generations of family medicine and primary care researchers. Everywhere he went, he both earned and paid respect. He was devoted the details of classification but comprehended the whole. He founded NAPCRG in a minimalist tradition and lived in youthful amazement at how the organization and its people had grown. At his last NAPCRG meeting, Maurice marveled aloud: 'Look at all the new, young members. I really feel like I can see the future."'

Moira Stewart: "At the 1975 NAPCRG meeting in San Francisco, Maurice asked a friendly question in public, and he followed up with a quiet one-on-one chat with me querying where my research program was going next! This was the quintessential positive challenge. I heard him say, at workshops in the 1970s and 80 s, that until we can describe our patients' problems and our work to respond to these problems, the field of primary care will remain a mystery, unsolved and, some may say, therefore irrelevant. And it must be done cor- 
rectly, reflecting the nuances of patients' presentations and the providers' responses. ICPC remains ahead of its time in recognizing the importance of coding what is unique about the discipline of family medicine."

Perry Dickinson: "As NAPCRG President during a period of rapid growth of the organization, I had multiple conversations with Maurice regarding the need to keep the warm, personal, and supportive nature of the meetings despite the large number of new people arriving on NAPCRG's doorstep. This is one of the things that has made NAPCRG meetings different and very generative, and Maurice deserves tremendous credit for instilling in our current leaders the importance of keeping that vision alive."

Carol Herbert: "Maurice saw the promise in the presenters at NAPCRG, rather than their limitations. I recall his helpful and supportive comments to me after my first presentations in 1977, when I was a community-based researcher. That this important man spoke to me directly reinforced my commitment to family medicine research and to NAPCRG. He was a mentor who treated me as a peer from our first meeting. I recall Maurice running annual general meetings at NAPCRG in the early years when he was President/ Executive Director. He received one dollar a year as executive director and the budget was not much. Meetings were short, but involved everyone at NAPCRG that year-registration made one a member. He would present what he was engaged in on behalf of NAPCRG, as well as the financial statement and then invite-and listen to-opinions from the floor. NAPCRG was the family of family medicine researchers, who were few in the 70's and 80's, and often isolated in our own communities - and Maurice was the dad!"

Bill Hogg: "I remember working with Maurice in the 1980s on the board of directors of the Ambulatory Sentinel Practice Network, a developing, bi-national practice-based research network. Maurice's joy in research was contagious and his conviction of its importance an inspiration. Family was also clearly very important to Maurice. Over the years when seeing him at meetings, he always spoke about his wife and children."

Jeannie Haggerty: "Maurice burned up the dance floor-enthusiastic dancer is putting it mildly. Dancing with one and all was a natural extension of his passion and supportiveness as a researcher. I welcomed and was inspired by his dedication to NAPCRG being a place of nurture and curiosity, not brutal critique and one-up-man-ship."

Walter Rosser: "Maurice was a wonderful human being in every aspect. He visited us in Hamilton when I was chair there, promoting research and talking about NAPCRG. He drove on to London, Ontario, to visit Ian McWhinney and Martin Bass. On his way he discovered that there was something wrong with the car as it wasn't steering properly. He stopped on the highway and discovered that someone had taken the new tires off the car and replaced them with threadbare tires. Cell phones were not available then so he had to wait at a gas station for a replacement car before continuing his journey. Such setbacks and delays must have happened on many occasions as he traveled the world promoting family medicine and primary care research, but it was Maurice the human being that absorbed such shocks without losing his kind and generous touch-at his next destination."

Ann Macaulay: "Maurice was full of enthusiasm for life in general, and I enjoyed his stories from his very varied past, which included being put in control of the locks of the Suez Canal when he was stationed in Egypt at the time of the Suez crisis - and where he met his beloved wife Erica. Maurice's vision of primary care research led him to continually support new ideas emerging at NAPCRG. In my case he was very supportive of those of us starting out in participatory research to develop research partnerships with community members and other stakeholders. Very early on he recognized this as an important research approach. How very perceptive he was-when we reflect on the continued growth of community-based participatory research and the current funding for community and patient engagement via the development of the United States' Patient-Centered Outcomes Research Institute."

Frank deGruy: "In 1992, Maurice Wood pulled me aside at NAPCRG and said: 'I'm really glad to learn that you're on the NIMH's Services Research Study Section. I just rotated off that thing and they really, really need a primary care person there. Those people don't know anything about primary care, and you will just have to teach them over and over again that half their ideas about what they want to do in primary care won't work. Remember, in primary care, you know what you're talking about and they don't, so be noisy. You are the expert, and they are not. Also, they're not very nice to each other, or to the people they review. Help them learn to be more supportive.' He was right, again."

Larry Green: "I was 28 years old and still in residency when I met Maurice at a NAPCRG meeting. He not only tolerated my youth and inexperience, he became my friend, mentoring me as if I were his equal. It was Maurice that found the $\$ 1,400$ in the NAPCRG budget to support exploration of a bi-national practicebased research network, the first investment in the US in such enterprise. I relish memories with him, eg his explaining to Kellogg Foundation representatives the necessity of practice-based evidence, meals and debates with Henk Lamberts about ordering principles of primary care, accompanying him to the Johns Hopkins 
celebration of the life and work of Barbara Starfield, joining him as his guest at the Metropolitan Opera before his last NAPCRG meeting — and his returning to the hotel after midnight, "a little tired." I am ever in his debt for cultivating ideas and people and being relentlessly kind to me. My world shrank when he left us."

Maurice Wood would be unhappy with this tribute if it did not acknowledge his own gratitude to his many colleagues, particularly Kerr White and Henk Lamberts, and especially to his home department of family medicine at Virginia Commonwealth University that provided him critical institutional support throughout his US career. Perhaps these words of song-writer Dan Fogelberg capture NAPCRG's deep appreciation for Maurice:

"The leader of the band is tired and his eyes are growing old.

But his blood runs through my instrument and his song is in my soul.

My life has been a poor attempt to imitate the man.

I'm just a living legacy to the leader of the band." ${ }^{15}$

Thank you, Maurice Wood!

\section{References}

1. Kermode-Scott B. Maurice Wood. BMJ. 2016;353:i2129.

2. Green LA. Maurice Wood: an appreciation. Br J Gen Pract. 2016;66(646):262.

3. WONCA International Classification Committee. International Classification of Primary Care ICPC-2-R. Revised 2nd ed. Oxford: Oxford University Press; 2005.

4. Marsland DW, Wood M, Mayo F. A data bank for patient care, curriculum, and research in family practice: 526,196 patient problems. J Fam Pract. 1976;3(1):25-28.

5. Fogelberg D. Leader of the band. http://www.google. $\mathrm{com} /$ ? ion $=1$ fespv $=2 \# q=$ leader $\% 20$ of $\% 20$ the $\% 20$ band $\% 2$ lyrics. Accessed May 9, 2016.

\section{\&AFP}

Ann Fam Med 2016;14:386-387. doi: 10.1370/afm.1955.

\section{MACRA READY: ACADEMY PRESIDENT ROLLS OUT MASSIVE MACRA COMMUNICATION EFFORT}

The AAFP officially launched a comprehensive member communication and education effort focused on the Medicare Access and CHIP Reauthorization Act (MACRA) at a Town Hall meeting in Kansas City, Missouri, on May 6, 2016.
AAFP President Wanda Filer, MD, MBA, of York, Pennsylvania, addressed family physicians and AAFP chapter leaders who filled a ballroom at the Academy's 2016 Leadership Conference (the combined Annual Chapter Leader Forum and National Conference of Constituency Leaders). Her remarks were also livestreamed to family physicians nationwide in a video that has been archived at http://www.aafp.org/practicemanagement/payment/macraready.html, the AAFP's MACRA Ready resource page.

"What I'd like to do now is introduce you to something that the Academy has devoted immense resources to and will continue to grow. This is a new multi-year member education and communication effort," Filer said as she presented the MACRA Ready site.

The AAFP's MACRA Ready site is a one-stop shop filled with resources family physicians can use right now such as

- A timeline of important dates

- A list of acronyms to help digest the alphabet soup associated with these complicated regulations

- A 60-second overview video

- A deep-dive review of what value-based payment means to family physicians, and much more

Filer told family physicians that the Academy's MACRA communication plan "is designed to help simplify the transition and provide the guidance that you will need to realize the benefits of MACRA and valuebased payments."

She noted that a recent AAFP survey indicated that some $40 \%$ of family physicians already were involved in some kind of value-based payment system.

"And so we may be positioned to be a little bit ahead of this curve as we move into the MACRA world," Filer said.

She gave her audience a brief history lesson on MACRA and why the AAFP supported the passage of the 2015 law that "repealed the flawed sustainable growth rate (SGR) formula that many of us spent the better part of probably 15 years on Capitol Hill working to get rid of."

MACRA not only repealed the SGR, said Filer, it also established an annual positive or flat-fee payment for the next 10 years, and it has instituted a 2-track program (the Merit-based Incentive Payment System and Alternative Payment Models) for calculating Medicare payment beginning in 2019, Filer reminded physicians.

"Passage of MACRA was the culmination of years of sustained lobbying and outreach by the house of medicine, the American Academy of Family Physicians and many of you in this room," she noted.

Filer then took that thought one step farther.

"Passage of MACRA is among the most significant change to occur in medicine in decades," she said. And 